\title{
Issues raised by extended campus services librarians
}

The Off-campus Library Services Conference proceedings state that the primary objective of this meeting is "to provide a forum where practitioners involved with library services for off-campus constituents [can] gather to exchange relevant ideas, concerns, and perspectives; and to share research." The fifth meeting of this conference did indeed provide a forum for participants, this time in Albuquerque, New Mexico from October 30-November 1,1991

Elizabeth J. Burge, distance learning coordinator at the Ontario Institute for Studies in Education addressed the opening session of the conference with a presentation titled "Relationships and responsibilities: Working together in distance education." Burge noted that it is the role of the offcampus academic librarian to mediate between the high-tech world of information storage and the high-stressed world of adult learners. She encouraged participants to build relationships and to delineate responsibilities with faculty and administration within higher education. At issue are the method and substance of the communication between the academic arm of the institution operating off-campus and the library services which support those offcampus activities. The conceptual framework described by Burge has seven mechanisms: program and course planning, marketing, resource development, data access, technical communications, services and materials delivery, and professional development. Burge concluded her presentation with discussions of professional identity, elegance, inclusion, and expectations, and related each to libraries and distance education.

\section{Share your opinion with $C d R L$ News readers}

Do you feel strongly about a particular issue and want to share your thoughts with a wider audience than just your colleagues down the hall? Now you have the opportunity to share your thoughts with a national audience. $C \& R L$ News is looking for wellreasoned commentaries on issues of interest to academic and research librarins for its new column,"The Way I See It." Essays should be between $500-750$ words and should be sent to "The WayISee It," CURLNews, ACRL, 50E. Huron St., Chicago, IL 60611-2795; fax: (312) 280-7663; email: U38398@UICVM.
Herbert S. White, distinguished professor in the School of Library and Information Science at Indiana University, spoke to the conference attendees about his experience with off-campus education and provided sorne advice to those who render offcampus library services. One of the themes of this presentation was the need for maintenance of quality. White argued that courses both on- and offcampus must result in the same outcomes regardless of who is teaching. In speaking about library services to individuals in out-of-the-way places, White suggested that there are no handicaps except for political barriers, and [that] political barriers are eliminated whenever those who have erected them decide it is worth their while." He further added that document delivery is easy between any two points within 48 hours and is possible within 24 hours; thus we must think in terms of bibliographic

\section{... it is the role of the off-campus academic librarian to mediate between the high-tech world of information storage and the high- stressed world of adult learners.}

access and document delivery and retrain the accrediting associations to think this same way. White concluded by stating that the U.S. "deserves an informational system which is not restricted by arbitrary boundaries of geography." Noting that need, opportunity, and ability are in evidence, he asked participants if librarians have the courage and conviction to provide this type of information access.

The conference's concurrent paper sessions addressed a variety of issues including bibliographic instruction, technology, services, marketing, accreditation, and research to better understand the off-campus library services environment. The author found a number of the presentations of interest, including those by Monica Collier (Central Michigan University), Lynda Fritz (University of Saskatchewan), and Jerilyn Marshall (Northwestern University) dealing with bibliographic instruction; Allen Dollerschell (Rochester Community College) on contracting for local services; Andrew Scrimgeour and Susan Potter (Regis University) 


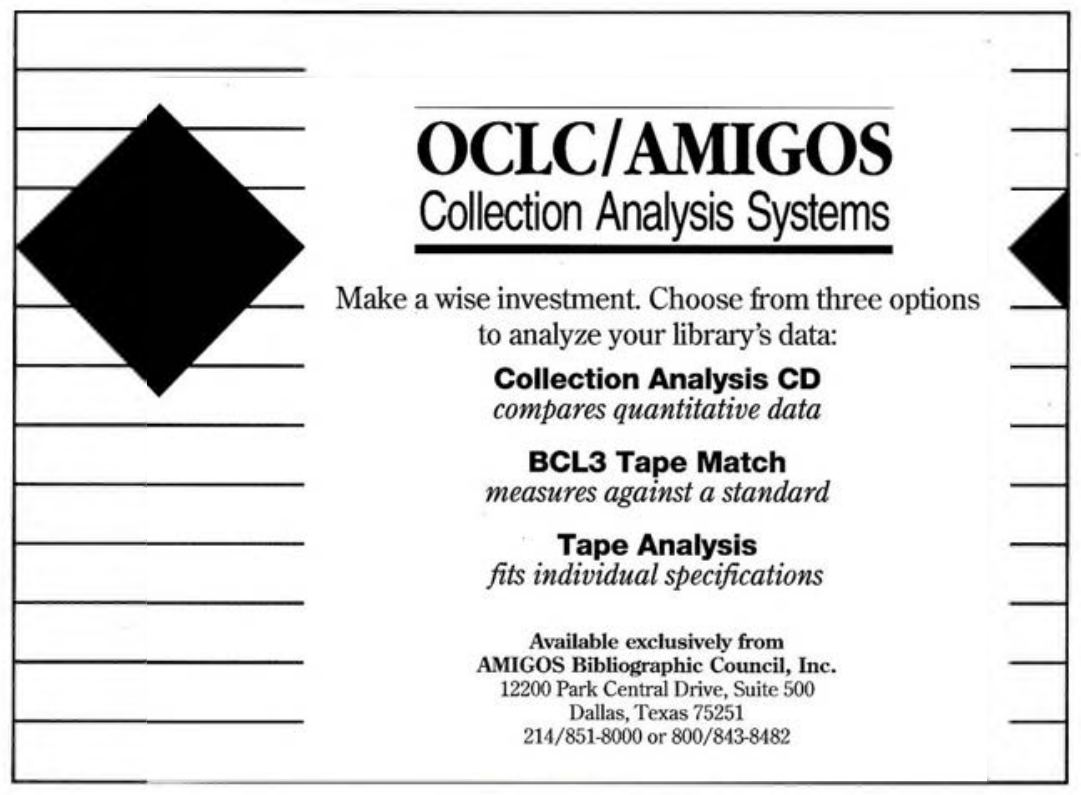

discussing the role and evolution of contracts; Thomas Abbott and Susan S. Lowe (University of Maine at Augusta) on the continuing development of offcampus library services in the state of Maine; Edward Garten (University of Dayton) and Kenneth Marks (East Carolina University) on aspects of the accreditation process and its relationship with offcampus services; Keith Cottam (University of Wyoming) about the efforts in Wyoming to enhance offcampus library services and to consider the future of off-campus library services generally; Alexander Slade (University of Victoria) on a librarian-centered model for development of off-campus library services; and Sheila Latham (University of Lethbridge) discussing 60 years of off-campus library services research. The concurrent sessions emphasized a number of themes, including the fact that while there are distinctions between off-campus services and those on-campus, there are also many aspects of service which are comparable regardless of location. Further, these sessions clearly illustrated a diversity of approach and response to the need to provide library services for the full range of an institution's constituents including those individuals who attend class and pursue library research off-campus.

One of the beneficiaries of this particular meeting was the ACRL Extended Campus Library Ser- vices Section. As the section was so well represented in Albuquerque, the conference afforded the opportunity for section officers and committee members to discuss plans for future meetings in San Antonio and San Francisco and to recruit new members with the support and participation of the conference organizers.

The Off-campus Library Services Conference was successful for a variety of reasons including the significant contributions of its speakers and the conscientious labor of its organizers, the staff of the Central Michigan University Libraries. The efforts to create a valuable program and a well organized conference were not lost on the 172 attendees representing 136 educational institutions, the United States, Canada, England, and the Barbados. As with the four previous meetings, attendees left wondering aloud where the next Offcampus Library Services Conference would be held. This conference continues to fulfill the promise of helping to move off-campus services toward the mainstream of academic library activity. For information on the conference proceedings and future sessions contact: Judith Porter, 207 Park Library, Central Michigan University, Mt. Pleasant, MI 48859; (517) 774-3500.-Barton $M$. Lessin, Assistant Dean of Libraries, Wayne State University 